\title{
Biorational control methods for protection of stored grain legumes against bruchid beetles
}

\author{
Takashi Yamane
}

National Agricultural Research Center, National Agriculture and Food Research Organization, Tsukuba, Japan; nemesis@affrc.go.jp

Received 24 October 2013; revised 25 November 2013; accepted 12 December 2013

Copyright (C) 2013 Takashi Yamane. This is an open access article distributed under the Creative Commons Attribution License, which permits unrestricted use, distribution, and reproduction in any medium, provided the original work is properly cited.

\begin{abstract}
Bruchid beetles such as Callosobruchus maculatus are known to the storage pests of grain legumes and cause tremendous damage. The main method to protect from them is chemical insecticides or fumigants. But, they would cause some problems such as environmental pollution, hazard to health. So, it is necessary to develop the grain legumes protection methods or systems using less chemical insecticides or fumigants from the perspective of integrated pest management (IPM). In this paper, I review the works of legumes grain protection methods without chemical insecticides or fumigants especially for the natural parasitoids, essential oils and other methods recently developed.
\end{abstract}

Keywords: Bruchid Beetles; Natural Parasitoids; Essential Oils; Temperature Management; Integrated Pest Management

\section{INTRODUCTION}

Chickpeas (Cicer arietinum L.) and cowpea (Vigna unguiculata Walp.) are important grain legumes grown in Asia, the Mediterranean, Australia, Canada, the USA, and Africa [1] and stored dry. However, they become infested by many insect pests both in the field and during postharvest storage. The most important pests of stored grain legume seeds are bruchid beetles (Coleoptera: Chrysomelidae: Bruchinae), such as Callosobruchus maculatus (F.) and Callosobruchus chinensis (L.) [2,3]. Even low initial infestation rates can lead to tremendous damage because of the beetles' high fertility and short generation times [4]. Each emerging female C. maculatus quickly finds a mate and, if food is readily available, produces about 100 offspring. After three or four generations, each of which takes only about a month, losses are severe [5-8]. Most subsistence farmers in developing countries rely on traditional storage structures, which are especially vulnerable to bruchid attack $[9,10]$. The use of insecticides or fumigants to protect the seeds from bruchids is effective, but these chemicals pose health hazards to farmers and consumers, cause environmental pollution, and cost money. Furthermore, insects develop resistance to insecticides, necessitating the application of larger amounts [11]. These problems can be reduced through the use of integrated pest management. This paper reviews alternative methods to protect against bruchid beetles. Breeding of crops for resistance to storage insects, especially bruchid beetles, has already been reviewed [12]. This paper focuses on parasitoids, essential oils, and recent new methods.

\section{BIOLOGIAL CONTROL METHODS}

\subsection{Natural Parasitoids}

Some wasps parasitize bruchid beetles (Table 1). Females of the wasps oviposit on the eggs, larvae, or pupae,

Table 1. Hymenopteran parasitoids species and their bruchid hosts.

\begin{tabular}{llc}
\hline Parasitoids species & Host species & Ref. \\
\hline \multirow{2}{*}{ Anisopteromalus calandrae } & Acanthoscelides obtectus & {$[13]$} \\
& Callosobruchus maculatus & {$[14]$} \\
& Zabrotes subfasciatus & {$[15]$} \\
\hline A. obtectus & {$[16]$} \\
& C. maculatus & {$[17,18]$} \\
Cinarmus basalis & C. chinensis & {$[19]$} \\
& C. subinnotatus & {$[20]$} \\
& Bruchidius atrolineatus & {$[16]$} \\
\hline Eupelmus vuilletii & Z. subfasciatus & {$[16]$} \\
\hline Uscana lariophaga & C. maculatus & {$[18]$} \\
\hline
\end{tabular}


and the emerged larvae feed on them. Dinarmus basalis (Rondani) (Hymenoptera: Pteromalidae) parasitizes lateinstar larvae and pupae of a wide range of beetle species, having a stronger impact on beetle populations than other species such as Eupelmus vuilletii (Crawford) (Hymenoptera: Eupelmidae) [18,22]. Uscana lariophaga Steffan (Hymenoptera: Trichogrammatidae) parasitizes eggs of $C$. maculatus and Bruchidius atrolineatus Pic (Coleoptera: Chrysomelidae: Bruchinae). The release of D. basalis adults in suitable numbers and under suitable conditions reduced populations of $C$. maculatus drastically and halted seed weight loss for 6-7 months in West Africa [20,23,24], and controlled Acanthoscelides obtectus (Say) in Colombia [25]. Uscana lariophaga significantly reduced the numbers of $C$. maculatus adults, the rate of damaged beans, and seed weight loss in a traditional storage system in Niger for 3 months [26]. Tracking of the phenological relationship between $A$. calandrae and $C$. maculatus populations over 5 months suggested that $A$. calandrae reduced the $C$. maculatus populations [27]. However, these parasitoids need suitable temperature and humidity to be effective as biological control agents. And within closed storage systems, populations of both hosts and parasitoids can reach high densities, which could lead to high intra- and inter-specific competition among parasitoids for the host resource as, for example, among $E$. vuilletii females [28] and between $E$. vuilletii and $D$. basalis $[18,22,29]$. Such competition may reduce the parasitoids' effectiveness at biological control, although the coexistence of $U$. lariophaga did not change the ability of $D$. basalis to suppress $C$. maculatus and damage to beans [30]. Before parasitoids are used as biological control agents, it is necessary to take into account the costs and benefits associated with the optimum environmental conditions, numbers, kinds, and combination of parasitoid species.

\subsection{Essential Oils}

Several plants and constituent bioactive substances, also called "insecticides of plant origin" or "botanical insecticides", have been tested against seed beetles. The effects of essential oils from some plant species on adult mortality, oviposition, $F_{1}$ adult emergence, and other behaviors of bruchid beetles, especially $C$. maculatus, by contact and fumigant treatment have been reported (Table 2). Essential oils comprise mainly monoterpenes,

Table 2. Sources of essential oils, target species, and effects and types of treatment.

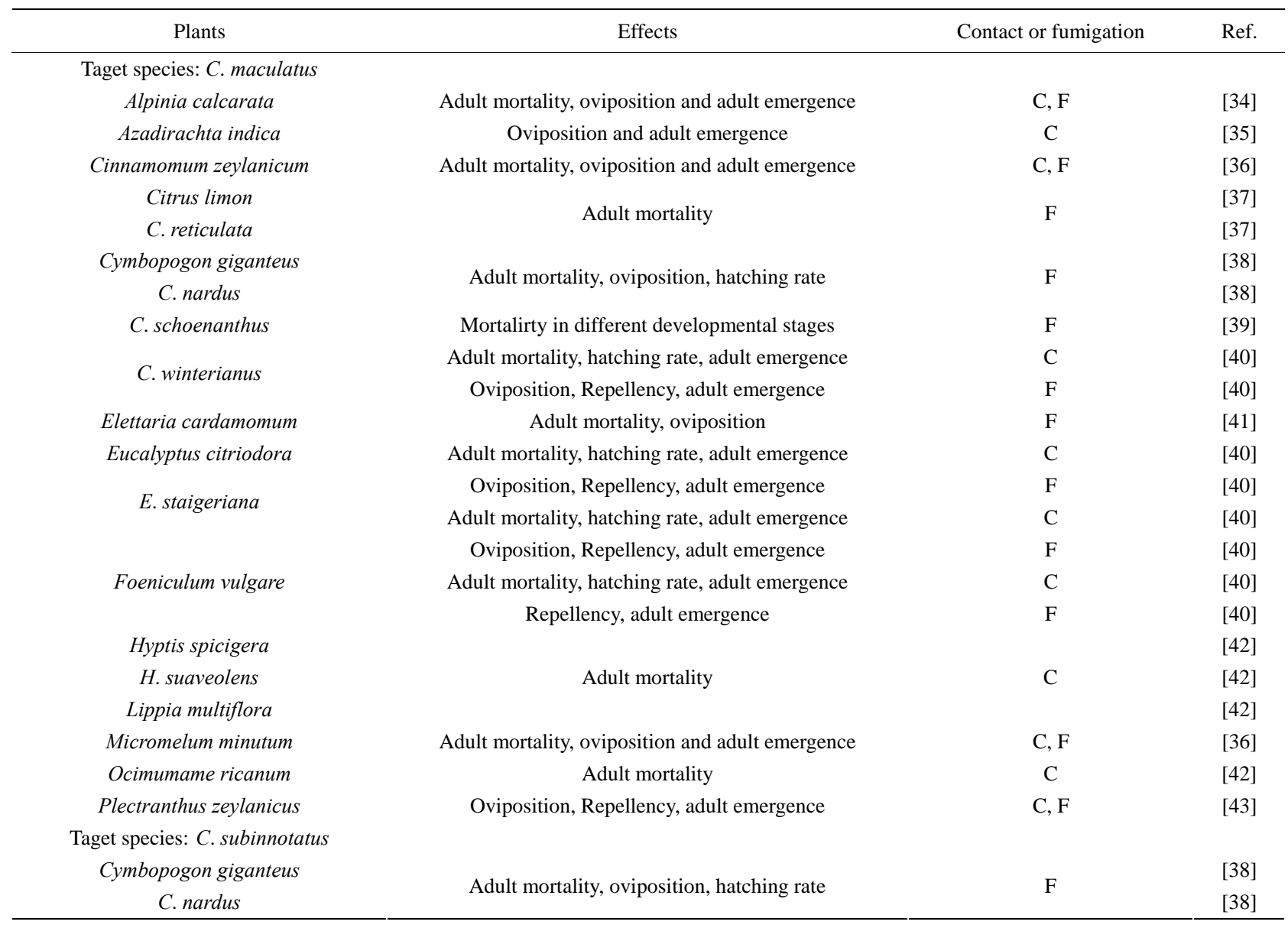


sesquiterpenes, and low-molecular-weight aromatic compounds [41]. Some monoterpenoids affect mortality at all developmental stages and oviposition [42]; and 1,8cineole from Alpinia calcarata (Rosc.) (Zingiberaceae) affects adult mortality, oviposition, and $F_{1}$ emergence [31]. However, essential oils are likely to affect predators as well. For example, essential oils of Cymbopogon nardus (L.), Cymbopogon schoenanthus (L.), and Ocimum basilicum (L.) increased the mortality of $D$. basalis larvae and pupae that parasitized $C$. maculatus, as well as $C$. maculatus [43]. In contrast to genetically modified legumes expressing $\alpha$-amylase inhibitor-1 of Phaseolus vulgaris L. or cysteine protease inhibitors, which are resistant to several bruchid species and should be compatible with the use of parasitoids [44], essential oils might not be compatible with the use of parasitoids.

\subsection{New Methods}

Temperature management is one of the most promising tools for controlling pests of stored grain [45]. Studies of the effects of both low and high temperatures on mortality of $C$. maculatus at different life stages give varying results, depending on the methods [46,47]. Although temperature control offers a way to disinfest beans, potential problems include the effect of the treatment on the beans and the cost of the equipment. Although low temperatures do not harm seeds, high temperature stimulated the germination of mung beans [48]. Further research of the effects of temperature, especially high temperature, is needed.

Hermetic storage bags (SuperGrainbags; GrainPro, Concord, MA, USA), which reduce internal oxygen levels, increased $C$. maculatus mortality and reduced invasion from outside when used to store cowpea [49].

\section{CONCLUTION}

Several methods may protect stored beans from bruchid beetles without the need for chemical insecticides, but adequate control might depend on a combination of methods. Combining methods would also reduce the likelihood of the development of resistance [11]. Neem oil could be combined with resistant cultivars for the management of $C$. maculatus [50]. The combination of arcelin, a protein associated with insect resistance in $P$. vulgaris, with biological control by $D$. basalis increased the mortality of $A$. obtectus relative to $D$. basalis alone [51,52]. Such combinations would support integrated pest management of bruchid beetles while reducing the use of chemical insecticides or fumigants.

\section{ACKNOWLEDGEMENTS}

This work was partly supported by Research Fellowships for Young Scientists (JSPS 233967).

\section{REFERENCES}

[1] Food and Agriculture Organization, "FAO Statistical Year Book,” FAOSTAT, 2010. http://www.faostat.fao.org

[2] Bushara, A.G. (1988) Insect depredation during storage. In: Summerfield, R.J., Ed., World Crops: Cool Season Food Legumes, Kluwer, Dordrecht, 367-378.

http://dx.doi.org/10.1007/978-94-009-2764-3_33

[3] Kashiwaba, K., Tomooka, N., Kaga, A., Han, O.K. and Vaughan, D.A. (2003) Characterization of resistance to three bruchid species (Callosobruchus spp., Coleoptera, Bruchidae) in cultivated rice bean (Vigna umbellata). Journal of Economic Entomology, 96, 207-213. http://dx.doi.org/10.1603/0022-0493-96.1.207

[4] Southgate, B.J. (1979) Biology of Bruchidae. Annual Review of Entomology, 24, 449-473. http://dx.doi.org/10.1146/annurev.en.24.010179.002313

[5] Caswell, G.H. (1961) The infestation of cowpeas in the western region of Nigeria. Tropical Science, 3, 154-158.

[6] Prevett, P.F. (1961) Field infestation of cowpea (Vigna unguiculata) pods by beetles of the families Bruchidae and Curculionidae in Northern Nigeria. Bulletin of Entomological Research, 52, 635-645. http://dx.doi.org/10.1017/S0007485300055668

[7] Alzouma, I. (1987) Reproduction et developpement de Bruchidius atrolineatus Pic (Coleoptera: Bruchidae) aux dépens de cultures de Vigna unguiculata L. Walp. (Leguminosae: Papilionacea) dans un agro système sahélien au Niger. Thèse de Doctorat, Université de Tours, Tours, 162.

[8] Germain, J.F., Monge, J.P. and Huignard, J. (1987) Development of two bruchid populations (Bruchidius atrolineatus (Pic) and Callosobruchus maculatus (Fab.)) infesting stored cowpeas (Vigna unguiculata Walp.) pods in Niger. Journal of Stored Products Research, 23, 157-162. http://dx.doi.org/10.1016/0022-474X(87)90045-2

[9] van Huis, A. (1991) Biological methods of bruchid control in the tropics: A review. Insect Science and Its Application, 12, 87-102.

[10] Nukenine, E.N. (2010) Stored product protection in Africa: Past, present and future. Proceedings of the 10th International Working Conference on Stored Product Protection, Julius-Kühn-Archiv, Berlin, 26-41.

[11] Boyer, S., Zhang, H. and Lempérière, G. (2012) A review of control methods and resistance mechanisms in storedproduct insects. Bulletin of Entomological Research, 102, 213-229. http://dx.doi.org/10.1017/S0007485311000654

[12] Keneni, G., Bekele, E., Getu, E., Imtiaz, M., Damte, T., Mulatu, B. and Dagne, K. (2011) Breeding food legumes for resistance to storage insect pests: potential and limitations. Sustainability, 3, 1399-1415. http://dx.doi.org/10.3390/su3091399

[13] Schmale, I., Wäckers, F.L., Cardona, C. and Dorn, S. (2001) Control potential of three hymenopteran parasitoid species against the bean weevil in stored beans: The effect of adult parasitoid nutrition on longevity and progeny production. Biological Control, 21, 134-139.

http://dx.doi.org/10.1006/bcon.2000.0911 
[14] Ghimire, M.N. and Phillips, T.W. (2007) Suitability of Five Species of Stored-Product Insects as Hosts for Development and Reproduction of the Parasitoid Anisopteromalus calandrae (Hymenoptera: Pteromalidae). Journal of Economic Entomology, 100, 1732-1739. http://dx.doi.org/10.1603/0022-0493(2007)100[1732:SOF SOS]2.0.CO;2

[15] Kistler, R.A. (1985) Host-age structure and parasitism in a laboratory system of two hymenopterous parasitoids and larvae of Zabrotes subfasciatus (Coleoptera: Bruchidae). Environmental Entomology, 14, 507-511.

[16] Rasplus, J.Y. (1989) Revision des especes afrotropicales du genre Dinarmus Thomson (Hymenoptera: Pteromalidae). Annales de la Societe Entomologique de France (N.S.), 25, 135-162.

[17] Amevoin, K. (1998) Activités reproductrices et réponses comportementales de Dinarmus basalis Rond. et de Eupelmus vuilleti Craw. en présence de leur hôte Callosobruchus maculatus $F$. en zone guinéenne au Togo. Thèse de Doctorat, Univ. Bénin (Togo), 156.

[18] Monge, J.P., Dupont, P., Idi, A. and Huignard, J. (1995) The consequences of interspecific competition between Dinarmus basalis (Rond) (Hymenoptera: Pteromalidae) and Eupelmus vuilleti (Crw) (Hymenoptera Eupelmidae) on the development of their host population. Acta Oecologia, 16, 19-30.

[19] Islam, W. and Kabir, S.M.H. (1995) Biological control potential of Dinarmus basalis (Rond.) (Hymenoptera: Pteromalidae), a larval-pupal ectoparasitoid of the pulse beetle, Callosobruchus chinensis (L.). Crop Protection, 14, 439-443. http://dx.doi.org/10.1016/0261-2194(94)00007-U

[20] Sanon, A., Ouedraogo, A.P., Tricault, Y. and Credland, P.F. (1998) Biological control ofbruchids in cowpea stores by release of Dinarmus basalis (Hymenoptera: Pteromalidae) adults. Environmental Entomology, 27, 717-725.

[21] Lammers P.M. and van Huis A. (1989) Uscana lariophaga Steffan (Hym. Trichogrammatidae), egg parasitoid of the stored insect pest Callosobruchus maculatus (F.) and Bruchidius atrolineatus Pic (Col. Bruchidae): Population studies in the fiels and storage in Niger. Proceedings of the International Conference on Integrated Pest Management in Tropical and Subtropical Ecosystems, 3, 1013-1022.

[22] Jaloux, B., Sanon, A., Huignard, J. and Monge, J.P. (2004) Interspecific relationships between the solitary ectoparasitoid, Eupelmus vuilleti (Crw.) (Eupelmidae), and Its Sympatric Species, Dinarmus basalis (Rond.) (Pteromalidae), in the Presence of Their Host, Callosobruchus maculatus Pic (Coleoptera Bruchidae). Journal of Insect Behavior, 17, 793-808.

http://dx.doi.org/10.1023/B:JOIR.0000048989.36181.4d

[23] Ouedraogo, P.A., Sou, S., Sanon, A., Monge, J.P., Huignard, J., Tran, B., Credland, P.F. (1996) Influence of temperature and humidity on populations of Callosobruchus maculatus (Coleoptera: Bruchidae) and its parasitoid $D i$ narmus basalis (Pteromalidae) in two climatic zones of Burkina Faso. Bulletin of Entomological Research, 86, 695-702. http://dx.doi.org/10.1017/S0007485300039213

[24] Amevoin, K., Sanon, A., Apossaba, M. and Glitho, I.A.
(2007) Biological control of bruchids infesting cowpea by the introduction of Dinarmus basalis (Rondani) (Hymenoptera: Pteromalidae) adults into farmers' stores in West Africa. Journal of Stored Products Research, 43, 240-247. http://dx.doi.org/10.1016/j.jspr.2006.06.004

[25] Schmale, I., Wäckers, F.L., Cardona, C. and Dorn, S. (2006) Biological control of the bean weevil, Acanthoscelides obtectus (Say) (Col.: Bruchidae), by the native parasitoid Dinarmus basalis (Rondani) (Hym.: Pteromalidae) on small-scale farms in Colombia. Journal of Stored Products Research, 42, 31-41.

http://dx.doi.org/10.1016/j.jspr.2004.10.005

[26] van Huis, A., Schütte, C. and Sagnia, S. (1998) The impact of the egg parasitoid Uscana lariophaga on Callosobruchus maculatus populations and the damage to cowpea in a traditional storage system. Entomologia Experimentalis et Applicata, 89, 289-295. http://dx.doi.org/10.1046/j.1570-7458.1998.00411.x

[27] Ngamo, T.S.L., Kouninki, H., Ladang, Y.D., Ngassoum, M.B., Mapongmestsem, P. M. and Hance, T. (2007) Potential of Anisopteromalus calandrae (Hymenoptera: Pteromalidae) as biocontrol agent of Callosobruchus maculatus (F.) (Coleopetera: Bruchidae). African Journal of Agricultural Research, 2, 168-172.

[28] Mohamad, R., Monge, J.P. and Goubault, M. (2010) Can subjective resource value affect aggressiveness and contest outcome in parasitoid wasps? Animal Behaviour, 80, 629-636. http://dx.doi.org/10.1016/j.anbehav.2010.06.022

[29] Mohamad, R., Monge, J.P. and Goubault, M. (2011) Agonistic interactions and their implications for parasitoid species coexistence. Behavioral Ecology, 22, 1114-1122. http://dx.doi.org/10.1093/beheco/arr098

[30] van Huis, A., van Alebeek, F.A.N., van Es, M. and Sagnia, S.B. (2002). Impact of the egg parasitoid Uscana lariophaga and the larval-pupal parasitoid Dinarmus basalis on Callosobruchus maculatus populations and cowpea losses. Entomologia Experimentalis et Applicata, 104, 289-297. http://dx.doi.org/10.1046/j.1570-7458.2002.01015.x

[31] Abeywickrama1, K., Adhikari, A.A.C.K., Paranagama, P. and Gamage, C.S.P. (2006) The efficacy of essential oil of Alpinia calcarata (Rosc.) and its major constituent, 1,8cineole, as protectants of cowpea against Callosobruchus maculatus (F.) (Coleoptera: Bruchidae). Canadian Journal of Plant Science, 86, 821-827.

[32] Lale, N.E.S. and Abdulrahman, H.T. (1999) Evaluation of neem (Azadirachta indica A. Juss) seed oil obtained by different methods and neem powder for the management of Callosobruchus maculatus (F.) (Coleoptera: Bruchidae) in stored cowpea. Journal of Stored Products Research, 35, $135-143$. http://dx.doi.org/10.1016/S0022-474X(98)00039-3

[33] Paranagama, P.A. and Gunasekera, J.J. (2011) The efficacy of the essential oils of Sri Lankan Cinnamomum zeylanicum fruit and Micromelum minutum leaf against Callosobruchus maculatus (F.) (Coleoptera: Bruchidae. Journal of Essential Oil Research, 23, 75-81. http://dx.doi.org/10.1080/10412905.2011.9700430

[34] Moravvej, G., Hassanzadeh-Khayyat, M. and Abbar, S. 
(2010) Vapor activity of essential oils extracted from fruit peels of two Citrus species against adults of Callosobruchus maculatus (Fabricius, 1775) (Coleoptera: Bruchidae). Turkish Journal of Entomology, 34, 279-288.

[35] Nyamador, W.S., Ketoh, G.K., Amevoin, K., Nuto, Y., Koumaglo, H.K. and Glitho, I.A. (2010) Variation in the susceptibility of two Callosobruchus species to essential oils. Journal of Stored Products Research, 46, 48-51. http://dx.doi.org/10.1016/j.jspr.2009.09.002

[36] Ketoh, G.K., Koumaglo, H.K. and Glitho, I.A. (2005) Inhibition of Callosobruchus maculatus (F.) (Coleoptera: Bruchidae), development with essential oil extracted from Cymbopogon schoenanthus L. Spreng. (Poacea), and the wasp Dinarmus basalis (Rondani) (Hymenoptera: Pteromalidae). Journal of Stored Products Research, 41, 363371. http://dx.doi.org/10.1016/j.jspr.2004.02.002

[37] Nivea, M.S., Gusmão, N.M.S., de Oliveira, J.V., Navarro, D.M. do A.F., Dutra, K.A., da Silva, W.A. and Wanderley, M.J.A. (2013) Contact and fumigant toxicity and repellency of Eucalyptus citriodora Hook., Eucalyptus staigeriana F., Cymbopogon winterianus Jowitt and Foeniculum vulgare Mill. essential oils in the management of Callosobruchus maculatus (FABR.) (Coleoptera: Chrysomelidae, Bruchinae). Journal of Stored Products Research, 54, 41-47. http://dx.doi.org/10.1016/j.jspr.2013.02.002

[38] Abbasipour H., Mahmoudvand M., Rastegar F. and Hosseinpour M.H. (2011) Insecticidal activity and chemical composition of the essential oil from cardamom, Elettaria cardamomum (Maton) against three stored-product insects. Journal of Insect Science, 11, 1-10. http://dx.doi.org/10.1673/031.011.16501

[39] Ilboudo, Z., Dabiré, L.C.B., Nébié, R.C.H., Dicko, I.O., Dugravot, S., Cortesero, A.M. and Sanon, A. (2010) Biological activity and persistence of four essential oils towards the main pest of stored cowpeas, Callosobruchus maculatus (F.) (Coleoptera: Bruchidae). Journal of Stored Products Research, 46, 124-128. http://dx.doi.org/10.1016/j.jspr.2009.12.002

[40] Balachandra, B.A.H.E., Pathirathna, P.U. and Parangama, P.A. (2011) Control of stored grain pest, Callosobruchus maculatus (F.) (Coleoptera: Bruchidae) using the essential oil isolated from Plectranthus zeylanicus. Natural Products Research, 26, 2219-2222.

[41] Knaak, N. and Fiuza, L.M. (2010) Potencial dos óleos essenciais de plantas no controle de insetos e microrganismos. Neotropical Biology and Conservation, 5, 120-132. http://dx.doi.org/10.4013/nbc.2010.52.08

[42] Mbata, G.N. and Payton, M.E. (2013) Effect of monoterpenoids on oviposition and mortality of Callosobruchus maculatus (F.) (Coleoptera: Bruchidae) under hermetic conditions. Journal of Stored Products Research, 53, 4347. http://dx.doi.org/10.1016/j.jspr.2013.02.001
[43] Ketoh, G.K., Glitho, I.A. and Huignard, J. (2002) Susceptibility of the bruchid Callosobruchus maculatus (F.) and its parasitoid Dinarmus basalis (Rond.) Hymenoptera Pteromalidae to three essential oils. Journal of Economic Entomology, 95, 174-182. http://dx.doi.org/10.1603/0022-0493-95.1.174

[44] Álvarez-Alfageme, F., Lüthi, C. and Romeis, J. (2012) Characterization of digestive enzymes of bruchid parasitoids-initial steps for environmental risk assessment of genetically modified legumes. PloS ONE, 7, Article ID: e36862. http://dx.doi.org/10.1371/journal.pone.0036862

[45] Fields, P.G. (1992) The control of stored-product insects and mites with extreme temperatures. Journal of Stored Products Research, 28, 89-118. http://dx.doi.org/10.1016/0022-474X(92)90018-L

[46] Johnson, J.A. and Valero, K.A. (2003) Use of commercial freezers to control cowpea weevil, Callosobruchus maculatus (Coleoptera: Bruchidae) in organic Garbanzo beans. Journal of Economic Entomology, 96, 1952-1957. http://dx.doi.org/10.1603/0022-0493-96.6.1952

[47] Loganathan, M., Jayas, D.S., Fields, P.G. and White, N.D.G. (2011) Low and high temperatures for the control of cowpea beetle, Callosobruchus maculatus (F.) (Coleoptera: Bruchidae) in chickpeas. Journal of Stored Products Research, 47, 244-248. http://dx.doi.org/10.1016/j.jspr.2011.03.005

[48] Purohit, P., Jayas, D.S., Yadav, B.K., Chelladurai, V., Fields, P.G. and White, N.D.G. (2013) Microwaves to control Callosobruchus maculatus in stored mung bean (Vigna radiata). Journal of Stored Products Research, 53, 19-22. http://dx.doi.org/10.1016/j.jspr.2013.01.002

[49] García-Lara, S., Ortíz-Islas, S. and Villers, P. (2013) Portable hermetic storage bag resistant to Prostephanus truncatus, Rhyzopertha dominica, and Callosobruchus maculatus. Journal of Stored Products Research, 54, 23-25. http://dx.doi.org/10.1016/j.jspr.2013.04.001

[50] Lale, N.E.S. and Mustapha, A. (2000) Potential of combining neem (Azadirachta indica A. Juss) seed oil with varietal resistance for the management of the cowpea bruchid, Callosobruchus maculatus (F.). Journal of Stored Products Research, 36, 215-222. http://dx.doi.org/10.1016/S0022-474X(99)00035-1

[51] Schmale, I., Wäckers, F.L., Cardona, C. and Dorn, S. (2003) Combining parasitoids and plant resistance for the control of the bruchid Acanthoscelides obtectus in stored beans. Journal of Stored Products Research, 39, 401-411. http://dx.doi.org/10.1016/S0022-474X(02)00034-6

[52] Velten, G., Rott, A.S., Conde-Petit, B.J., Cardona, C. and Dorn, S. (2008) Improved bruchid management through favorable host plant traits and natural enemies. Biological Control, 47, 133-140. http://dx.doi.org/10.1016/j.biocontrol.2008.07.009 